\title{
LA CHAKANA Y LA CRUZ CRISTIANA: RITUALES, RELIGIÓN, FIESTAS, IDEOLOGÍASY SIMBOLOGÍAS EN LOS CONJUNTOS DE SIKURIS URBANOS
}

\author{
CARlos DANIEL SÁNCHEZ HuARINGA \\ UNIVERSIDAD NACIONAL MAYOR DE SAN MARCOS \\ karlos_202@hotmail.com
}

\section{RESUMEN}

La Fiesta de las Cruces tiene una importancia inusitada en el altiplano y este mismo ha sido recreado por los conjuntos urbanos de sikuris en Lima desde la década de los 80 en adelante. Se trata de una de las fiestas religiosas más esperadas por este movimiento urbano que se caracteriza por sus discursos ideológicos de izquierda marxista conjugados con utopía andina. Estos portan como elemento central de la fiesta y de veneración a la cruz cristiana y la cruz andina llamada chakana.

Palabras clave: chakana, cruz, sikuris, rituales, religiosidad, ideología.

\section{Abstract}

The Feast of the Crosses has an unusual importance in the plateau and this same one has been recreated by the urban groups of sikuris in Lima from the decade of the 80 onwards. It is one of the most anticipated religious festivals by this urban movement that is characterized by its ideological discourses of the Marxist left conjugated with Andean utopia. These bear as central element of the feast and of veneration to the Christian cross and the Andean cross called chakana.

KeYwords: Cchakana, cross, sikuris, rituals, religiosity, ideology. 


\section{INTRODUCCIÓN}

Los sikuris metropolitanos, urbanos o limeños son agrupaciones juveniles (principalmente estudiantiles de nivel superior) que se forman a inicios de los años 80 por influencia-directa o indirecta- de los conjuntos de sikuris regionales ${ }^{1}$. Su motivación principal es el "trabajo cultural artístico de rescate, investigación y difusión del arte altiplánico denunciando las repercusiones de la colonialidad y del sistema capitalista, como la marginación, la alienación cultural y la explotación.”2 De esta manera, desde esta práctica artística critican el "modelo capitalista" y apuestan por una utópica "sistema socialista" que revalore la "cultura andina"s. Pudimos anotar aproximadamente un centenar de este tipo de conjuntos que han existido a lo largo de estas cuatro décadas, muchos de ellos desaparecieron en el tiempo y otros tanto han nacido de igual forma, muchos y los más importantes son universitarios y los demás son grupos barriales. En general estos han tenido un desarrollo difuso a lo largo de estas cuatro décadas: Un primer momento (en los 80), de crecimiento en un contexto de crítica social y vigencia de los discursos marxista donde la utopía andina y la comunista fueron vitales para sus desarrollos. Un segundo momento de vacío ("crisis") durante los 90, época que se caracteriza por la caída de las ideas comunistas, una depreciación de la utopía andina y un profundo recambio generacional a nivel universitario. Finalmente los años 2000 que marca un nuevo apogeo del movimiento pero con caracteres urbanos sustancialmente distintos a los años 80 fundamentalmente por las nuevas generaciones que forman parte de ella.

Claramente estas agrupaciones tienen un "carácter urbano y juvenil”, contrario a los conjuntos de migrantes altiplánicos que expresan tradición rural, lazos de parentesco y paisanazgo, alta tradicionalidad de sus costumbres culturales (entre ellas las religiosas) y es conformado mayoritariamente por adultos. El padre Manuel Marzal, decía sobre los migrantes andinos a la capital: "Cuando los hombres andinos van a la ciudad (...) deben no sólo satisfacer sus necesidades básicas de supervivencia, sino también reorganizar su visión del mundo y, especialmente, su religión." (Marzal 1988: 86). Sin embargo, los conjuntos autodenominados "metropolitanos" si bien se encuentra conformado por una juventud con experiencia migratoria, no tienen una misma pertenencia ni tradición geográfica (no tienen lazos de "paisanazgo") y por su carácter intelectual, son prácticamente críticos (sino ateos) de todo tipo de religiosidad incluyendo la cristiana y la andina. Es decir estamos ante un movimiento sustancialmente cultural y social muy distinto.

Estos son partícipes mayoritarios de las fiestas llamadas "chakana cruz" que se desarrolla en Lima anualmente en tiempos de fiesta de cruces (03 de mayo), es una "fiesta de cruces" en realidad a la cual han denominado "chakana" en alusión y tomando como elemento central de veneración y fiesta al símbolo antiquísimo (ya está en la sociedad Chavín) de la chakana o cruz andina o cruz cuadrada. En esta fiesta, su organización y sucesión se rige por el esquema andino, se usa el modelo de "alferados" (mayordomos, alféreces, etc.) y aynis. Es presentado y pensado formalmente como una "fiesta religiosa" propia del movimiento sikuri limeño (metropolitano y regional), pero sus características

1. Los conjuntos de sikuris regionales son agrupaciones de migrantes altiplánicos que reproducen esta práctica artística como parte de sus reinterpretaciones de vida cultural en la capital limeña. Un extenso trabajo descriptivo sobre ellos se encuentra en Carlos Sánchez 2013.

2. Estatutos del Conjunto de Zampoñas de la Universidad Nacional Mayor de San Marcos (UNMSM) 1996. Mimeo. Estos lineamientos son comunes a los demás conjuntos de sikuris aparecidos metropolitanos en la época.

3. Con la variable "sistema socialista" hacen referencia al modelo económico político y social propuesto por los partidos políticos marxistas a nivel mundial y en el caso de "cultura andina" se refieren igual al sistema de vida de orígenes prehispánicos que se mantendría hasta la actualidad vía un proceso de "resistencia." Se supone que son dos "sistemas sociales" compatibles. 
formales y la acción de sus actores nos suscitan suspicacias y necesarias preguntas que intentaremos develar en el presente, principalmente ¿Qué tiene que ver el símbolo antiquísimo de la chakana (cruz andina) con las expresiones de religiosidad que estos conjuntos intentan expresar o reconstruir en pleno siglo XXI?
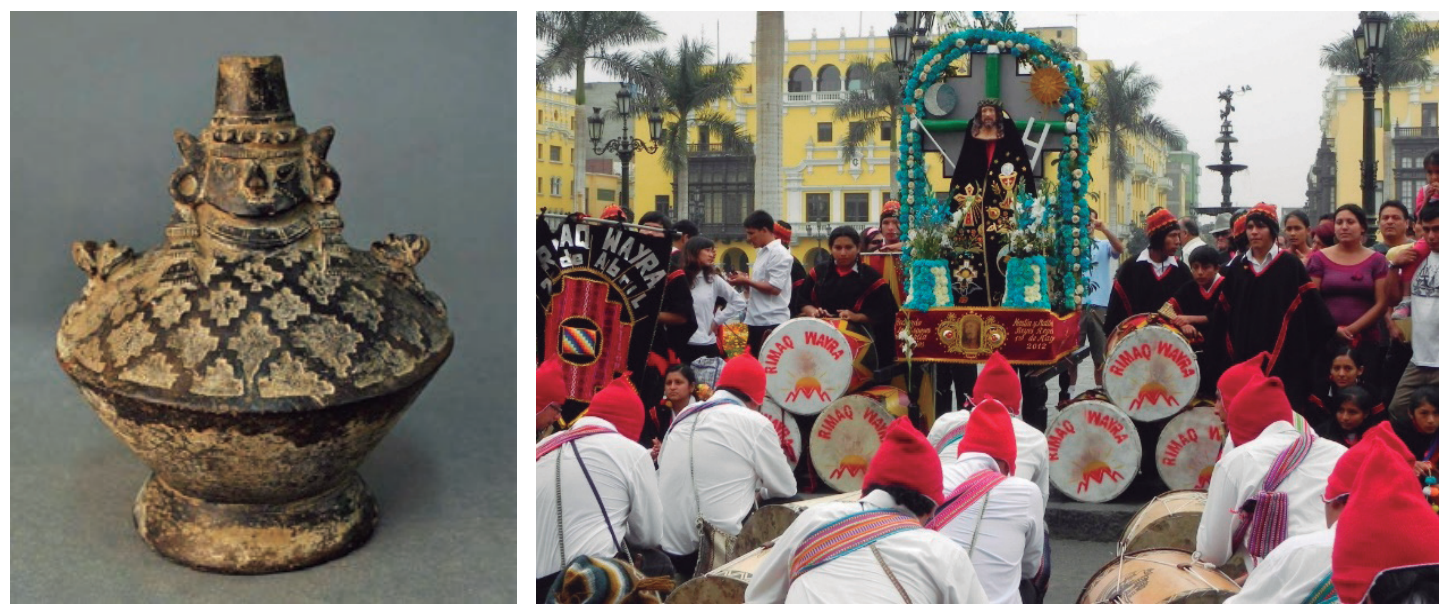

Fig. 1) El símbolo de la Chakana en la sociedad Chimú - Lambayeque del Intermedio Tardío y el Conjunto de Zampoñas de San Marcos, agrupación artística conformada por jóvenes universitarios estudiantes de la Universidad Nacional Mayor de San Marcos, "venerando" a las imágenes de la chakana y a la Cruz Cristiana

\section{La Fiesta de las Cruces, la Chakana o la Cruz Andina, la Constelación de la Cruz del Sur, las Huancas y la Cruz Cristiana}

\section{La Fiesta de las Cruces}

La fiesta de las cruces en el Perú en su versión que conocemos en la actualidad, se instaura obviamente con la imposición hispana durante la colonia bajo la denominación de "Festividad de la Cruz de Mayo". Se dice sobre esta:

"Era de carácter popular celebrándose con ritos especiales, entrando en todos ellos como elemento principal las flores; ya se adornaban con ellas altares provisionales junto a las puertas de las casas y en los patios, ya se llenan con ellas cestas y platillos que llevan los niños y niñas pidiendo el famoso cuartito para la Cruz de Mayo. (Schaw 1996: 54)".

Esta Fiesta de La Cruz se instituyó en Europa en el siglo IV en conmemoración por el supuesto hallazgo de la Cruz de Cristo, luego es instaurada en España por la iglesia, llega al mundo andino superponiéndola sobre una de las festividades y rituales andinos más significativos: la fiesta de la mamazara en algunos casos y en otros con los rituales y fiestas en agradecimiento a las cosechas o fiesta de troje (almacenamiento). Se trataba de un gran acontecimiento en la medida que la cosecha y el guardado de los alimentos constituía un momento decisivo para la futura alimentación de las poblaciones. El maíz, en la medida que era considerada el alimento por excelencia, daba lugar a un gran acontecimiento al momento de su cosecha y almacenamiento. Generaba también ritos festivos 
de agradecimiento a la pachamama por sus frutos brindados (esta etapa es también considerado como el pasaje a un nuevo año):

"El mundo católico celebra durante todo mayo la Fiesta de la Cruz, el 3 de mayo se conmemora el supuesto hallazgo del madero donde fue crucificado Jesús. Como sabemos, la devoción a este símbolo del catolicismo llegó al Perú con los españoles. Pero mayo era también una fecha especial para los pueblos prehispánicos. En el antiguo Perú se celebraba la festividad denominada Hatun Aymoray Quilla, una fiesta que celebraba la cosecha del maíz: mamasara o saramama. Otros investigadores afirman que se rendía culto a la Pachamama en agradecimiento por la buena cosecha. Si bien en la Colonia los españoles superponen la celebración religiosa oficial sobre la costumbre andina, en la práctica ocurre un mestizaje. Así vemos que en varios pueblos del Perú la fiesta en honor a la Cruz de Mayo está cargada de sincretismo ${ }^{4 "}$.

Federico Schaw (1996) desarrolla la idea de que la Fiesta de las Cruces, como imposición hispana, tiene hasta la actualidad muchos ritos agrícolas cuyos orígenes se encuentran en antiguas tradiciones festivas agrícolas prehispánicas. Es muy enfático al señalar la superposición y posterior conjugación o sincretismo de la Fiesta de la Cruz hispana con festividades y rituales andinos de orígenes pre incas: "la invención de la fiesta de la Santa Cruz debe haberse fusionado en el Perú con una fiesta autóctona anterior relacionada probablemente con algún rito agrícola." (p.60) De esta manera se explicaría por qué en la actualidad encontramos "muchas fiestas de cruces" (así en plural) y con diferentes características o elementos peculiares que indicarían una posible continuidad de devoción a antiguas divinidades locales autóctonas.

La fiesta de las cruces de mayo en su versión puneña fue reimplantada en Lima por los migrantes altiplánicos más allá de la mitad del siglo XX, y a inicios de la década de los 80 la Asociación Juvenil Puno (AJP) organiza una fiesta de la cruz agrupándose con sikuris regionales amigos. Esta "creación" se hace como parte del "trabajo cultural e ideológico" que la AJP tenía como proyecto entonces, el hecho de denominar y luego juntar físicamente la chakana con la cruz cristiana nos sugiere la racionalidad instrumental con la que nace. Poco a poco a esta novísima fiesta se unirán los conjuntos metropolitanos hasta ser los más activos y mayoritarios conjuntos agrupados alrededor de este evento supuestamente religioso:

La AJP en los 70 trajo el siku e inició su resembrado a nivel nacional, en los 80 trajo la Festividad de la "Chakana Cruz" a Lima para celebrarla como en las comunidades (...) A inicios de la década de los 80, la Asociación Juvenil Puno organizó una actividad en los primeros días del mes de mayo, denominándola Festividad de la "Chakana Cruz", según la concepción aymara (...) cuando la fiesta estaba finalizando, los concurrentes se preguntaron quién sería el nuevo alferado para el próximo año y voluntariamente se ofreció el conjunto de Sikuri "San Miguel de Tuito" (Hancco 2012: 8).

\section{La ChaKana}

La referencia más citada de la cruz cuadrada, cruz andina, cruz chakana (o chakana simplemente) es la del cronista aymara Juan de Santa Cruz Pachacuti Yanqui Salcamayhua en su obra Crónica de relación de antigüedades de este reino Pirú (1613). En el gráfico que hizo del templo del Coricancha muy utilizado en los estudios antropológicos para desarrollar temas de cosmovisión andina, se observa la constelación de la Cruz (conocida como Cruz del Sur por la cultura occidental) a la cual llamó 
"chakana" (fig. 3). Esta es traducida en la actualidad como "puente" o "escalera"; se supone que es la escalera que une el mundo de arriba y el mundo terrenal. Desde este "descubrimiento" de la chakana se construirá -exclusivamente en el terreno intelectual a lo largo del siglo XX-diversas hipótesis sobre su existencia, función y simbología. Se trata de investigaciones sobre todo arqueológicas y en el campo de la historia en la medida en que la vigencia o el uso específico de la chakana desapareció en algún tiempo de la historia andina pre hispánica o colonial, vale decir que el símbolo no se encuentra vigente en ningún momento de las poblaciones andinas, sino racionalizado como forma reconstruida por grupos específicos e interesados en el tema.
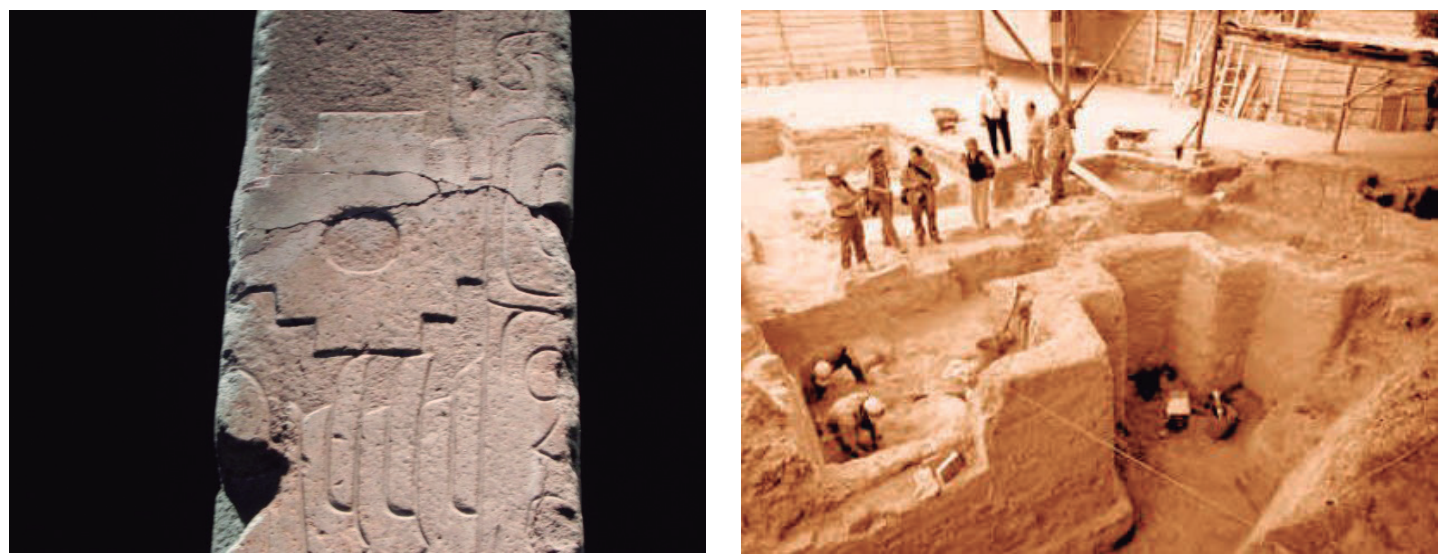

Fig. 2) Evidencias de la Chakana en la etapa Pre hispánica: a) Cultura Chavín, el símbolo se encuentran en el Obelisco Tello y también en el Lanzón Monolítico. b) Cultura Mochica en la vista una estructura arquitectónica parece tener la forma, además, es común en otros restos cerámicos e iconográficos.

La cruz cuadrada andina o chakana tendría sus orígenes simbólicos en la constelación del Sur o la Cruz del Sur, su estructura geométrica perfecta lleva a suponer que fue el símbolo filosófico más grande del mundo andino. Para los investigadores e ideólogos andinistas como el arquitecto Carlos Milla, la Cruz Chakana sintetiza la ciencia andina misma, la matriz de concepción del ordenamiento general del mundo andino. Por ejemplo, indicaría la estructuración del Tawantinsuyo (cuatro caminos) y del Qhapak Ñan (camino Inka), entre otros. Se trata de la piedra filosofal del conocimiento y que no tiene un contenido específicamente religioso, aunque la ciencia y la religión en el mundo andino se encuentran íntimamente relacionadas, por lo que pudo haber estado afecto a algún tipo de rituales. Este símbolo ciertamente aparece graficado en las más grandes y principales culturas andinas: en centros ceremoniales de la cultura Pukara (Altiplano), en la Portada del Sol en Tiawanaco, en el Obelisco de Chavín, en los mantos de Paracas, en la cultura Mochica, en los ceramios Nasca, en Wari, en el altar de la ciudadela de Chan Chan, y últimamente también descubierta en Caral ${ }^{5}$. Todo esto indica que ciertamente se trata del símbolo de la cosmovisión andina por excelencia, representación del universo y su concepción (Milla 1983). Por ello es presentada -en estos tiempos y por una corriente de pensamiento-, como la síntesis del conocimiento, la ciencia o estructura (cosmovisión) del mundo andino. Veamos un poco más sobre estas ideas tejidas alrededor del símbolo de la chakana ${ }^{6}$ :

5. Carlos Milla (1983) dice que la constelación de la Cruz del Sur ya se halla asociada a un yacimiento pre-cerámico con más de 6000 años de antigüedad.

6. "La Chakana es una cruz cuadrada con los bordes escalonados cuyo centro forma un vacío que representa a la 
La Cruz Cuadrada es el símbolo que permite ver el resumen esquemático de la cosmovisión andina; la misma que engloba conceptos ancestrales. Por ende, es un símbolo de misteriosos ordenamientos matemáticos y naturales; cuyo centro es un círculo hueco, el cual significa el vacío central que representa a Dios. Su creación está dividida en cuatro reinos o cuatro zonas; que a su vez se relacionan o identifican con las cuatro estaciones de la Tierra, los cuatro elementos de la naturaleza -Agua, Tierra, Fuego y Aire-, y los cuatro puntos cardinales. Expresa también su concepto de la dualidad en el equilibrio de polaridades: día-noche, arriba-abajo, derecha-izquierda, al frente-atrás, dulce-salado, oscuridad-luz, hombre-mujer, alegría-tristeza, bien-mal, Dios-Demonio, negativo-positivo, etc. Los lados de la cruz, con tres escalones cada uno, representan los tres Mundos de la cosmovisión andina: Uku Pacha (subsuelo), Kay Pacha (superficie), Hanan Pacha (Cielo), con sus cuatro lados igualmente proporcionales. Por esto se la conoce como "La Cruz Perfecta", pues en ella se encierra el significado de muerte y resurrección; se conjuga en la horizontal y la vertical, fuerza centrípeta y centrifuga, la unión del cielo y la tierra, y la reconciliación del creador con su creación. Es el símbolo de la complementariedad de los opuestos; dialéctica de fuerzas contrarias que se confrontan sin aniquilarse; es la circularidad del tiempo que transcurre en el cielo, y termina para dar paso a otro ciclo ${ }^{7}$.

Al margen de estas sugerentes ideas, cierto es que para los antiguos andinos la Constelación de la Cruz del Sur debe haber tenido una importancia altamente significativa en la medida en que señala el pasaje a la época de las cosechas, al tiempo seco, momento en que el cielo andino se limpia totalmente y se refleja nítidamente la constelación del Sur, un tiempo que posiblemente marque el inicio del "año nuevo andino": "Todos los cronistas señalan cuatro fiestas principales durante el año: el Inti Raymi (fiesta del sol), el Capac Raymi (fiesta del Inca), el Cituay (fiesta de purificación) y el Aymoray (fiesta de las cosechas)" (Calsín 2010: 127). Los cronistas de la época señalan esta fiesta como una de las más importantes: "Mayo aymoray quilla mes de almacenar cosecha. Este mes se llama cortar calchay, de recoger zara arcuy (...) se debe recoger también yuyos, verduras y secarlas para hogaño y tener qué comer..." (Guamán Poma: 1615 / 2011: 663). Polo de Ondergardo, recogido por Vilcapoma (2008), nos dice:

"El sexto mes se llama Atún Cuzqui raymoray que responde a mayo, también se sacrificaban otros cien carneros de todos colores. En esta Luna y mes (que es cuando se trae el mayz de la era a la casa) se hazia la fiesta que oy día es muy vsada entre los indios que llaman, Amoral vel Aymoraña. Esta fiesta se haze viniendo desde la chacra hasta su casa diziendo ciertos cantares, en que ruegan que dure mucho el mayz hazen cada vno en su casa una huaca del mayz la cual llaman Mamaqara, tomando de su chacra cierta parte del mayz más señalado en cantidad y poniéndola en una troxe pequeña que llaman Pirua, tiene, y que está tapado y aderezado adoran esta Pirua, y la tienen en gran veneración, y dizen que es madre del mayz de su chacra y que en esto se da y se conserva el mayz, y por este mes le hazen un sacrificio particular y los hechizeros le preguntan si tiene fuerza para el año que viene y si responde que no le llevan a quemar a la misma chacra con la solemnidad que cada uno puede (Vilcapoma 2008: 235)".

Divinidad y lo que lo rodea su creación; la Chakana está dividida en cuatro reinos con tres escalones cada uno, significando los tres mundos: Uku Pacha (subsuelo), Kay Pacha (superficie) y Hanan Pacha (cielo). En el desierto de Chao (entre los valles del Virú y Santa, en Perú), el arq. Carlos Milla Villena, ubicó un geoglifo que representa la Constelación Chakana (Cruz del Sur), asociada a un yacimiento pre-cerámico de 6.000 años de antigüedad. Esto nos indica no sólo el conocimiento de esa constelación en ese entonces, sino además la importancia que se le daba a ella." Recogido de "Orígenes míticos de la fiesta andina de la cruz del sur o cruz de mayo" Willka Jankani. En: http://argentina.indymedia.org/

7. En: http://cruzcuadrada.com 
Estas fiestas o rituales del aimoray coincidían o se aproximaban temporalmente con la fiesta religiosa en honor a la Santísima Cruz que se celebraba desde siglos antes en el Viejo Continente, lo que facilitó de esta manera la superposición y posterior sincretismo con los rituales y festividades andinas del aymoray o la fiesta del mamazara. De la diversa conjugación de estas dos festividades (una agrícola y la otra religiosa) va a devenir las actuales sincréticas y masivas "fiestas de las cruces", en unas regiones más cristianizadas que en otras. Federico Schaw (1996) señala que las actuales fiestas de las cruces andinas (a partir de su estudio en la sierra central peruana) expresan o contienen antiguos rituales agrarios pre cristianos, rituales de agradecimiento a sus divinidades por la cosecha y abundancia del maíz (fiesta del mamazara). Deja entrever que muy poco de religioso tendrían estas fiestas hasta la Colonia, y no emite referencias sobre una fiesta en honor o que conecte a la constelación de la Cruz de Sur o a la cruz cuadrada andina o chakana:

"La fiesta de la mamazara se trata de un rito mágico antes que de un acto religioso. En la esfera incaica (...) la fiesta de la cosecha del maíz se depuró de los elementos mágicos, siendo estos desplazados por actos religiosos en forma de sacrificios al Sol (y) la fiesta de la Cruz (en el caso de Huancayo) tal como se celebra hoy se basa en la antigua fiesta del aymoray y la primera debe su amplia difusión y gran popularidad a la importancia que tuvo la última como una de las fiestas principales del antiguo Perú" (Schaw 1996: 62).

\section{LAS HUANCAS (HUACAS)}

Por otro lado, estos rituales (o fiestas) de agradecimiento por las cosechas y a la Pachamama, también se van a conjugar en muchos lugares del mundo andino o van a coincidir con la existencia y devoción a las huancas, a la que también llamaron huacas (fig. 3). Se trata de divinidades familiares y locales protectoras de la tierra (de las chacras, a las que en otros lugares también se les conoce como conopas o mallcos), de las casas, de los poblados, de los caminos, de las chacras; divinidades sanadoras, también de fertilidad, de abundancia, y a quienes se les rendía mayor devoción en tiempos de cosecha según el investigador José Gonzáles (1989). La devoción ritual y festiva a las huancas sería claramente de orígenes pre inca y estaban circunscritas básicamente a ámbitos familiares y locales. Es muchos casos fueron posiblemente anteriores y diferentes a la fiesta del aimoray. Estas divinidades, aún en muchos lugares llamados huancas hasta hoy, se simbolizaban en unas piedras u otros elementos que, significando la presencia sagrada de las divinidades andinas, tenían la función principalmente de brindar protección o bienestar a las unidades familiares, pueblos y caminos; estos puntos de reverencia durante la Colonia fueron prioritariamente reemplazados por las cruces cristianas:

"las conopas y mallcos, ídolos para la protección y buena producción de los maizales y papales, también fueron reemplazadas por la cruz (...) a las lluvias, el rayo y el trueno que hacían germinar y florecer los campos se los reemplazó con cruces (...) a las viviendas para su protección se colocaron cruces en los techos luego del zafacasa reemplazando las cunuvas llenas de maíz y cereales (...) los españoles a pesar del adoctrinamiento, la cristianización y la extirpación de idolatrías, que significó también la destrucción física de todos sus ídolos, no pudieron desaparecerlas y por ello sustituyeron a gran parte de las divinidades indígenas por cruces, para que los indios en lugar de adorar a sus dioses adorasen al símbolo sagrado del cristianismo." (Ramírez: 2009: 195).

Estas "pequeñas” y locales divinidades son diversos y abundantes dependiendo de las localidades, por ejemplo, en el caso de Huamantanga (Canta, provincia de Lima), encontramos diferentes y abundantes huacas/huancas e ídolos de acuerdo al Dr. Cajavilca (2007): "Los ídolos de piedra, símbolos religiosos andinos llenaban con su sensibilidad y su omnipotencia el espacio cotidiano de cada uno de los pobla- 
dores. Estos símbolos religiosos de piedra fueron destruidos por los extirpadores de idolatrías." (p. 228). Nombra algunos de estos ídolos: Ticllawacho (ídolo de piedra huanca que sanaba enfermedades), Sulca Vilca (ídolo de piedra con rostro de varón), Chontavillca (ídolo de piedra enterrado), Pacarina Aura (peñasco donde tienen sus mallquis), Yaropalpa (ídolo de piedra ordinaria sentado sobre la tierra), Chinchaypalpa (piedra sin ninguna figura), Guaracani (ídolo confesor), Pomaguato (ídolo de piedra en medio de la laguna Pomaguato), Condormalqui (piedra enterrada, que es llamada malqui y al que adoran para tener abundancia), Malmay (hijo de la huaca Pomaguato, dentro de la laguna y es dios de las comidas), Guachaura (piedra pequeña como negra, dios de las chacras), Yunguy (piedra tosca, la mitad negra y la mitad blanca), Coriguanca, Mallmain y otros.

\section{La CRuz Cristiana}

Por otro lado, la cultura occidental trajo la cruz cristiana como símbolo principal de "civilización”, de sometimiento y devoción, la misma que guarda cierta similitud geométrica formal con la cruz chakana, con la constelación del Sur, y coincide con la fecha festiva en su honor. Estos rasgos coincidentes no pudieron ser menos aprovechados en la consecución de su deseada evangelización o extirpación de idolatrías y facilitó la superposición sobre los rituales a las huancas, y en especial sobre los rituales festivos en honor a la mamazara o fiestas del aymoray. Desde entonces asistiremos a la instauración de la fiesta de la Cruz Velakuy, fiesta de la Vera Cruz o Cruz de Mayo, que se insertará cada vez con mayor profundidad en el sistema de fiestas andino y en el mundo subjetivo religioso del poblador. De esta manera se impone la fiesta en honor a la Santa Cruz que el mundo occidental había instituido celebrarse todos los 3 de mayo y los 14 de setiembre ${ }^{8}$. Esta superposición terminó en un sincretismo festivo y religioso con el paso del tiempo, desde entonces sabemos de una gran cantidad de poblados andinos que rinden culto a la cruz cristiana:

"La Cruz tiene una dimensión infinita, una elevación espiritual, por eso está en las altas cumbres con sed de espacio, está incorporada a nuestro espacio, a nuestro folklore, a los trabajos agrarios, a nuestra arquitectura, está como hitos que señalan caminos, indica el lugar de un desgraciado accidente, está en los cantos populares, preside los cabildos de las Comunidades, está en la vara de los Varayoq, está sobre la tumba y en todos los aspectos de la vida del hombre andino" (Altamirano 1998: 86).

8. "Los libros litúrgicos contienen dos fiestas dedicadas al culto de la Cruz: La Invención de la Santa Cruz, el 3 de mayo, y la Exaltación, el 14 de septiembre. La Exaltación, que conmemora la dedicación de las basílicas de Jerusalén, es de origen oriental y no pasó a occidente hasta fines del siglo VII, a través del rito romano. La Invención de la Santa Cruz, en cambio, es conmemorada desde antiguo. En España aparece en todos los calendarios y fuentes litúrgicas mozárabes, poniéndola en relación con el relato del hallazgo por Santa Elena de la auténtica Cruz de Cristo. Este relato figura en los pasionarios del siglo X y puede resumirse así: En el sexto año de su reinado, el emperador Constantino se enfrenta contra los bárbaros a orillas del Danubio. Se considera imposible la victoria a causa de la magnitud del ejército enemigo. Una noche Constantino tiene una visión: en el cielo se apareció brillante la Cruz de Cristo y encima de ella unas palabras, In hoc signo vincis ("Con esta señal vencerás"). El emperador hizo construir una Cruz y la puso al frente de su ejército, que entonces venció sin dificultad a la multitud enemiga. De vuelta a la ciudad, averiguado el significado de la Cruz, Constantino se hizo bautizar en la religión cristiana y mandó edificar iglesias. Enseguida envió a su madre, santa Elena, a Jerusalén en busca de la verdadera Cruz de Cristo. Una vez en la ciudad sagrada, Elena mandó llamar a los más sabios sacerdotes y con torturas consiguió la confesión del lugar donde se encontraba la Cruz a Judas (luego San Judas, obispo de Jerusalén). En el monte donde la tradición situaba la muerte de Cristo, encontraron tres cruces ocultas. Para descubrir cuál de ellas era la verdadera las colocaron una a una sobre un joven muerto, el cual resucitó al serle impuesta la tercera, la de Cristo. Santa Elena murió rogando a todos los que creen en Cristo que celebraran la conmemoración del día en que fue encontrada la Cruz, el tres de mayo". (Antonio Merino 1997). 


\section{Las "Fiestas" (Rituales) de la Chakana}

De acuerdo a las descripciones de los cronistas, en las postrimerías del imperio incaico, no encontramos festividades conocidas específicamente como Chakana Cruz o Chakana Raymi, tampoco encontramos referencias sobre una fiesta religiosa en honor o en devoción a la Chakana Cruz o a la constelación de la Cruz del Sur, sino fiestas o rituales agrarios conocidos como aymoray con una temática explícita sobre el guardado (troje) de las cosechas (en especial del maíz) y sobre las cuales se habrían ido superponiendo las fiestas religiosas en honor a la cruz cristiana. Denominaciones y eventos como la Chakana Raymi van a surgir explícitamente en el siglo XX como parte de descubrimientos e investigaciones y vía extrapolaciones que intentan plasmar prácticas rituales a cargo de organizaciones que trabajan el tema indígena y que principalmente se encuentran involucrados en proyectos ideológicos de revaloración y actualización de elementos o costumbres andinas extinguidas. Esta articulación de la chakana con las actuales fiestas de la cruz, va a construirse entonces más como un grupo de proyecciones intelectuales a partir del hallazgo de cuantiosos vestigios de este símbolo en casi todas las culturas andinas pre hispánicas y su posible relación con la constelación de la Cruz del Sur (de la cual se supone que deviene su forma geométrica). Además va a estar sustentada por su presencia y denominación de "chakana" en el "mapa de la cosmovisión andina" dejado por el cronista aymara Juan de Santa Cruz. La presencia de la chakana cruz en este nuevo escenario se va a enfatizar en el Altiplano y en el área andina sureña del continente, donde es muy común su reinvención como antecedente de las fiestas de las Cruces sobre la base de la presencia del símbolo de la chakana que ha sido bastante frecuente en las diferentes culturas altiplánicas pre incaicas como Pukara, Pukina y Tiwanaku.

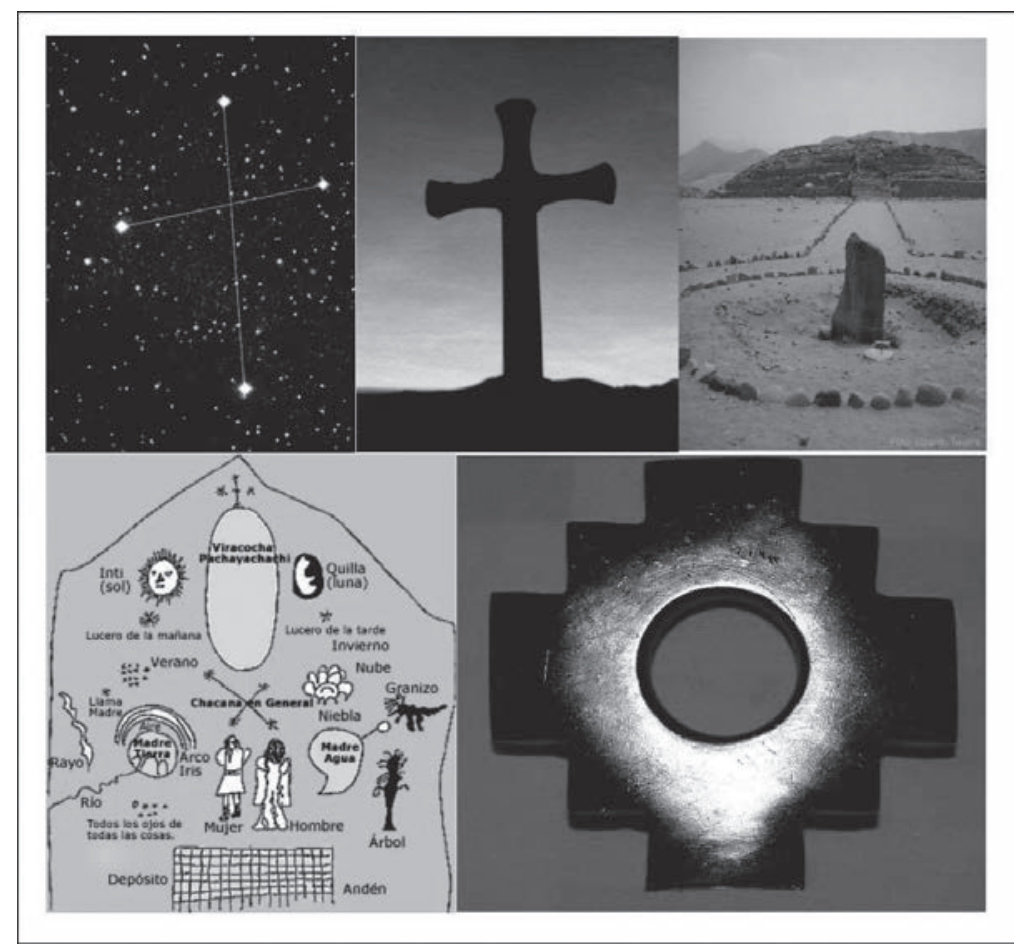

Fig. 3) La conjunción de estos símbolos culturales se entremezclan entre los discursos de los conjuntos metropolitanos de manera enrevesada: 1) Constelación de la Cruz del Sur, 2) Cruz Cristiana, 3) La Huanca, 4) Esquema de la Cosmovisión Andina, 5) Símbolo de la Chakana o cruz andina. 
Entonces no hallamos fiestas tradicionales y populares denominados Chakana Cruz o Chakana Raymi en ningún lugar del territorio andino, tampoco hay antecedentes de que hubieran existido, sino que desde hace algunas décadas asistimos a la aparición focalizada de estos eventos protagonizados por organizaciones ideológicas pro indígenas que albergan proyectos específicos como el retorno de perdidos cultos antiquísimos. Estos aseveran la existencia de rituales y festividades Chakana Raymi en honor a la constelación de la Cruz del Sur y que posteriormente habrían sido superpuestos por las fiestas cristianas de Cruces:

"Los invasores hispanos traen una cruz que guarda similitud geométrica formal con la Cruz cuadrada y la Cruz del Sur (llamada Chacana, en su síntesis) que es nuestra cruz andina. Aprovechando esta coincidencia plagian el símbolo de la Chacana afirmando que nuestras cruces y la cruz cristiana simbolizan por igual a su religión mediterránea, y con este engaño, típico método colonialista, lograron dominar al habitante andino, ideológicamente. La Chakana, es una cruz cuadrada con los bordes escalonados cuyo centro forma un vacío que representa a la Divinidad y lo que lo rodea su creación; la Chacana está dividida en cuatro reinos con tres escalones cada uno, significando los tres mundos: ukupacha (subsuelo), kaypacha (superficie) y hananpacha (cielo). Los Extirpadores de Idolatrías se las arreglaron para suplantar la milenaria fiesta andina de la Cruz del Sur con una seudo celebración cristiana que denominó Cruz Velakuy, fiesta de la Vera Cruz o Cruz de Mayo. Nuestra cruz de estrellas, símbolo material de la Verdad de una cultura cósmica, no tiene nada que ver con la exótica cruz que trajeron los invasores..."”.

De esta manera, instituciones milenaristas o neo indigenistas como el Movimiento Tawantinsuyano y otros, han popularizado eventos en torno a la Chakana Raymi. Sin embargo, estas reuniones más que festivas son pensadas en una especie de esoterismo con creencias y honores a las divinidades andinas, apoyadas en discursos milenaristas y mitológicos. Son por lo tanto pequeños círculos sociales que en muchos casos terminan realizando específicamente sesiones de espiritualidad. Veamos algunos eventos realizados por estas organizaciones, el título o términos que utilizan, el formato, cómo los presentan y el carácter que encierran:

- El “Primer Chakana Raymi ‘Chawpi Pacha' Fiesta de la Constelación de Sur” realizado entre el 1 y 2 de mayo de 2010 (Quito, Ecuador). El “Chakana Raymi, celebración de la Chakana” entre el 2 y el 4 de mayo de 2006 (Salta, Argentina).

- "Chakatana Raymi, Fiesta de la Cruz Andina" realizada el 2 de mayo de 2010 en el centro arqueológico de Pachacamac (Lima, Perú). Dice la publicidad virtual: "esta ceremonia tiene el objetivo de energizar a los presentes y al planeta tierra ya que la 'constelación de la Cruz del Sur' alcanza su mayor esplendor y es posible recibir todos sus beneficiosos influjos energéticos".

- "Chakana Raymi, celebración de la constelación madre chakana" a realizarse entre el 30 de abril y el 2 de mayo de 2010 (Córdoba, Argentina). Dice la convocatoria: "Como todos los años se organiza este sábado la fiesta de la Chakana Raymi, que es la observación del cielo y las estrellas a través de la cosmovisión andina en relación a la posición de la Cruz del Sur, para averiguar y conocer el tiempo de producción del año, el desarrollo de las actividades y el significado del pensamiento y comportamiento del hombre. Esta actividad de la Chakana Raymi es parte de la cultura de los quechuas y aymaras, se repite cada mes de mayo con la intención de recuperar el pensamiento y los conocimientos de los antepasados". Se realizó el 8 de mayo de 2010 (Potosí, Bolivia). 


\section{Reinvención de la "Fiesta de la Chakana Cruz" por los Sikuris Limeños: La Chakana y la Cruz Andina, Posturas Ideológicas}

La fiesta de la chakana cruz de los conjuntos de sikuris de Lima, se ha constituido como un nuevo espacio o momento de encuentro, donde la motivación participativa es básicamente la exhibición y competencia musical y la expresión de identidades grupales. No se percibe una "real" motivación religiosa. Este hecho hace que el símbolo religioso que se turnan en el cuidado y llevan en andas el día de la fiesta, esté constituido por la cruz cristiana y la cruz andina o chakana, dos símbolos que expresan "lo occidental" y "lo andino" en un juego de hibridez aparentemente ilógico, con nula devoción y sin feligreses. (Sánchez 2010: 17).

\section{Las Fiestas de las Cruces en Lima}

De las fiestas religiosas populares en el mundo andino, las cruces son más abundantes que las fiestas de veneración a Cristo, a la Virgen María y a los santos cristianos o santos patrones. Esto mismo se reproduce en Lima. El padre Manuel Marzal nos sugiere que esta tendencia se debe a que la cruz es un símbolo muy utilizado desde la Conquista como emblema de ocupación y afirmación; es por ello que en las décadas de las masivas migraciones a Lima, la cruz ha acompañado a las poblaciones en su necesidad de ocupación, legitimación y amparo de sus conquistas geográficas (las "invasiones" en los AA. HH.), sociales (organizaciones, asociaciones, clubes o instituciones) y simbólicas (creencias). También se encuentra el uso significante de la cruz como símbolo cristiano en sí mismo, cual representación de Dios en el lugar, así como la continuación de sus tradicionales fiestas o devociones a las cruces en sus lugares de origen. Además es conocido que el símbolo más usado para estigmatizar o suplantar a las numerosas huacas o divinidades andinas fue la cruz cristiana. Por ello se piensa que en casas, comunidades, caminos y cerros donde se encuentran hoy pequeñas o grandes cruces, fueron asientos de las huacas:

Es notable la importancia de la cruz como símbolo de veneración y culto religioso, que supera a los símbolos de Cristo y de la Virgen María (...) esto se explica no sólo por el lugar de la cruz en el culto cristiano, sino porque la cruz es un símbolo de ocupación de un territorio, tanto en la tradición hispánica de la conquista como en la tradición eclesiástica de los concilios limeños que mandaban poner una cruz en los cerros y adoratorios prehispánicos (Marzal 1989: 104).

Así, las fiestas en honor a la Cruz en Lima aparecen no solo como el traslado de tradiciones de los migrantes, sino también como un evento religioso reinventado en la ciudad, en nuevos escenarios como mercaditos, barrios, asociaciones, confraternidades, etc., y por diversas agrupaciones sociales, por lo que es seguro que cada fiesta de la cruz en la gran Lima tiene propias características. Marzal (Op. Cit.) En un pequeño trabajo de campo en la parroquia del distrito de El Agustino en Lima, por los años 80, encontró que solo en ese distrito se realizaban 19 fiestas de cruces, seis fiestas de cristos y nueve fiestas de vírgenes. Sin duda, la devoción a la cruz es muy emblemática y representativa en la religiosidad popular de los migrantes en Lima. 


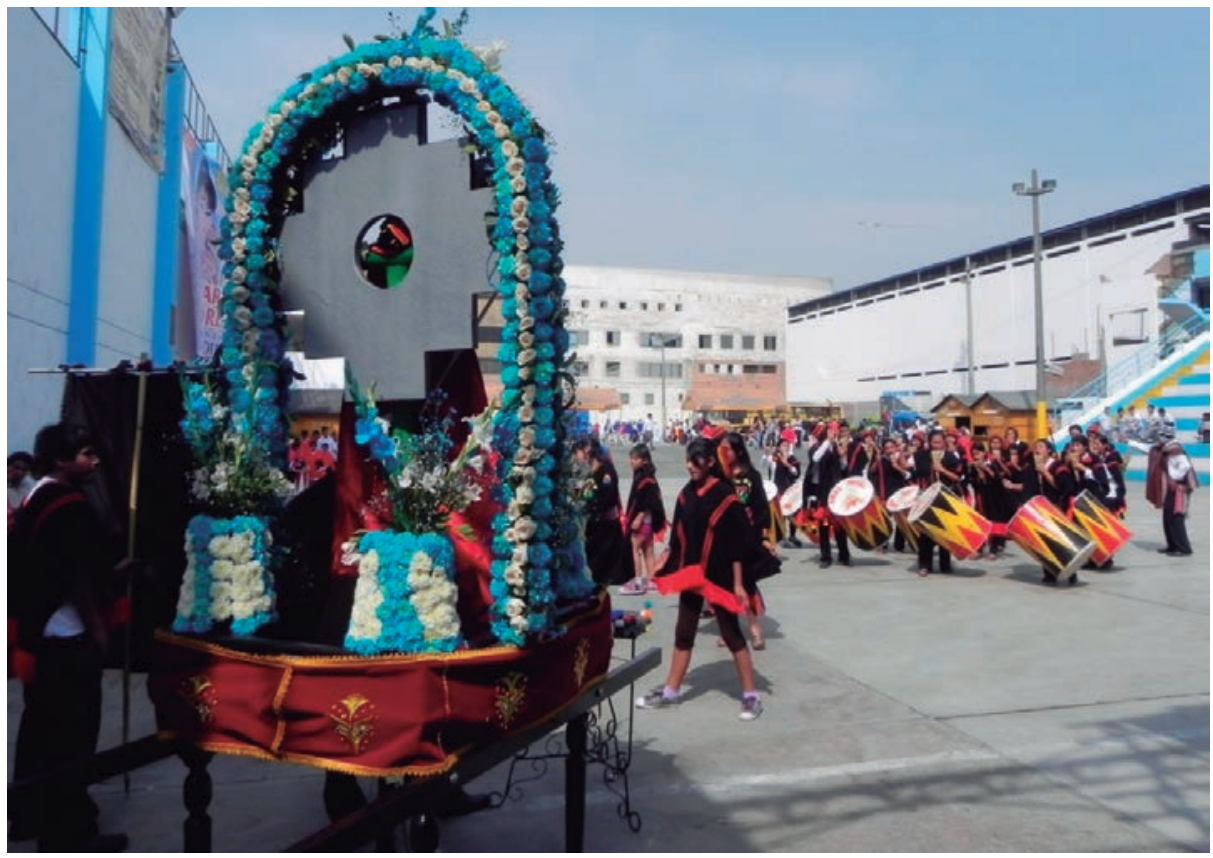

Fig. 4) Los conjuntos de sikuris limeños urbanos o metropolitanos son en la actualidad los principales actores de la continuidad de una fiesta que es a todas luces una "nueva" fiesta, muy juvenil y urbana presenta por ello elementos culturales hibridizados.

\section{La Fiesta de las Cruces en Huancané (Puno)}

La fiesta de la Cruz de Mayo en el Altiplano como en todo el Ande peruano, es también muy masiva, tiene la trascendencia de ser una fiesta de los sikuris y se desarrolla con más efusividad en el pueblo (hoy provincia) de Huancané. Esta se denomina popularmente fiesta de la Santísima Cruz de Mayo (ojo: no encontramos la denominación chakana cruz). En esta festividad se movilizan más de una veintena de cruces con sus respectivos mayordomos y sus grupos de sikuris contratados especialmente para acompañar los días de fiesta. En esta semana el pueblo huancaneño es centro de atención de todas las comunidades de los alrededores que incluso llegan con sus propias cruces al pueblo para ser parte de los rituales y de la fiesta, siempre acompañados por los grupos de sikuris (también de otros tipos de conjuntos de músicos coreográficos como los puli puli). También es ocasión para que los diferentes grupos de sikuris del Altiplano visiten el pueblo con o sin contrato de por medio; por ello la fiesta de las cruces en Huancané se convierte, por una semana, en la reunión más grande de grupos de sikuris y exclusivamente de la modalidad sikuri (sikuris de varios bombos o sikuri mayor) y de distinta procedencia: conjuntos campesinos, comuneros y aquellos formados a manera de organizaciones exclusivamente musicales ${ }^{10}$.

10. Las diferencias entre estos "dos tipos" de sikuris es evidente: los primeros se reúnen casi exclusivamente para la ocasión, presentan grandes rasgos de naturalidad y tradicionalidad en sus acciones y expresiones, en su técnica musical y vestimenta, no actúan por contratos y su participación en esta fecha es por devoción. Mientras los segundos son grupos constituidos en la ciudad misma de Huancané y sus acciones, expresiones y expectativas son las de grupos netamente musicales, los contratos para que ellos actúen son evidentes. 


\section{REINVENCIÓN DE LA FIESTA DE LAS CRUCES POR LOS SIKURIS LIMEÑOS}

Hacia 1980 la Asociación Juvenil Puno, inicia o reinventa, como parte de su racionalizado "trabajo cultural", una fiesta de cruces a la que van a llamar desde entonces Chakana Cruz. Se trata de una "réplica" de la fiesta de las cruces de la provincia de Huancané (Puno) y se intenta construirla bajo el formato regional de continuidad cultural o conservación de costumbres y tradiciones. Así, con todas las deficiencias o características de una "imitación" y un evento incipiente, empieza a desarrollarse pensando en un evento aglutinador de los conjuntos de sikuris de Lima principalmente regionales, llevando entonces impresa una discriminación hacia los conjuntos metropolitanos (carácter además propio de la relación regional y metropolitano en la década de los 80). El Conjunto de Zampoñas de San Marcos (CZSM) fue el primer conjunto metropolitano que se integra a esta fiesta haciéndose alferado en los años 1986, 1989 y luego en 1997, iniciando de esta manera el acercamiento de los conjuntos urbanos y que llevará en adelante a una plena integración de estos ya que ninguna regla se establece para ser parte de esta; solo la presencia y fortaleza del conjunto, medida en su accionar cotidiano, será garantía de confiabilidad. De esta manera este evento, de supuesto carácter religioso, va a ser concebido más como programa cultural e ingresará a un proceso de reacomodos de acuerdo a su nuevo contexto y a la particularidad de sus miembros: la Asociación Juvenil Puno (AJP), los grupos de sikuris regionales (los que tienen más actividad urbana) y los conjuntos metropolitanos ${ }^{11}$.

En los primeros años participaron en esta novedosa fiesta los siguientes grupos regionales: San Miguel de Tuito, Centro Social Conima, 29 de setiembre de Conima, Qantati Ururi de Conima y Sankayos de Moho, también conjuntos metropolitanos como el CZSM y Runa Taki. Estos se reunieron por convocatoria de la AJP para "festejar" la fiesta de la Cruz de Mayo. Cuentan que el primer año no contaban con una cruz y tuvieron que pintarla en la pared para repetir los rituales de devoción. El ritual festivo consistió en tocar, bailar y tomar licor. A lo largo de los años la fiesta fue "tomando forma", el alferado siguiente (el que se sucedía en el cargo para organizar la fiesta), construyó la cruz con dos maderos simples y una modesta anda, los demás rituales básicos fueron diseñados para los grupos que deseaban participar y la invitación fue para los demás grupos de sikuris de Lima. Con el transcurrir de los años la fiesta empezó a ganar presencia entre los grupos de sikuris metropolitanos que encontraron básicamente una ocasión de reencuentro, de fiesta, antes que un ritual de devoción y fe cristiana o andina.

\section{Simbolismos RELIGIOSOS Y SIGNIFICACIONES IDEOLÓGICAS}

En primer lugar el ingreso del término como del símbolo de la chakana (materializada en un gran madero que carga sobre sus espaldas la cruz cristiana) evidencia el uso ideológico de este y el proyecto político cultural de este movimiento: la recuperación de lo auténticamente andino frente a lo enajenante occidental. Simboliza el proyecto de recuperación de elementos profundamente andinos que los españoles destruyeron o intentaron destruir y suplantar, como los lugares sagrados y los elementos que los materializaban: las huacas, ídolos, rituales frente a la existencia de la cruz, la iglesia, los santos y los curas católicos. En los inicios de esta fiesta (años 80) y cuando los conjuntos metropolitanos todavía no se habían incluido en ella, el anda solo portaba a la cruz cristiana, pero a finales de los años 90 e inicios de los 2000, con la fuerte presencia metropolitana aparecerá físicamente la cruz chakana colocada en "las espaldas" de la cruz cristiana. Representará el momento más elevado de la

11. Participan en esta fiesta los grupos regionales que mayor actividad urbana tienen, es decir aquellos que salen de su ámbito tradicional y se consideran conjuntos musicales propiamente, y además se interrelacionan con los metropolitanos. En el movimiento metropolitano serán los grupos más ideologizados (llamados "radicales") los que no van a participar a estos eventos, obviamente que esta postura tiene mucho que ver con la concepción que la ideología marxista tiene de la religión. 
racionalizada idealización andinista base de los proyectos metropolitanos, más aún en la medida en que se trata del uso racional e instrumental del símbolo andino más intrigante, autóctono pero a la vez desaparecido ${ }^{12}$. En esta extrapolación ingresa con vigorosidad la chakana como un símbolo recuperado presuponiendo la supervivencia de muchos elementos o formas religiosas andinas escondidos bajo rituales cristianos. "Recuperada" (después de cinco siglos de tinieblas) la chakana reaparece tratando de simbolizar rituales pulcros, místicos, profundamente andinos relacionados a sanaciones, curas, carga de energías, e inclusive como símbolo ecológico. Aunque estos se presentan como continuidades de rituales extinguidos, su extraño formato disidente de las costumbres mismas de las poblaciones los delata.

De esta manera se da vida a esta fiesta de la cruz sustentada en los argumentos de la antropología andina clásica del siglo XX, lo que es considerado casi una verdad absoluta: "Bajo el símbolo de la cruzy bajo el amparo de las iglesias, el indio continuó creyendo en su realidad religiosa y venerando las fuerzas que él consideraba determinantes y poderosas en su mundo" (Schaw 1996: 74).

Sin embargo, Carlos Milla, el estudioso y defensor más acérrimo de la chakana andina, nos alerta con sorpresa al verla actualmente ingresando en la iglesia junto a la cruz cristiana. Se trata de un símbolo, nos dice, que nada tiene que ver con la religión cristiana, pues la chakana es sobre todo un símbolo científico, matemático: "La Cruz Cuadrada es una figura geométrica utilizada como símbolo ordenador de los conceptos matemáticos religiosos en el mundo (...) es geométrico y proporcional, fue usado como modulador y ordenador de los espacios arquitectónicos, urbanos y regionales en el Estado Comunitario Andino del Tawantinsuyu o Pusisuyu." (Milla 1983: 122). Pero estas voces no son oídas por los sikuris quienes parecen haber hallado en la chakana el símbolo de oposición al desvarío occidental, resaltan eso sí el esfuerzo de Milla por haber dedicado largas investigaciones a la chakana (además gustaban de sus radicales peroratas contra la cultura de occidente).

Así la fiesta de la chakana cruz de los conjuntos de sikuris de Lima llevará impresa el proyecto ideológico, cultural y político de las instituciones andinistas de los 80; sustentando el enfrentamiento y antagonismo mental, de lo andino frente al sistema de pensamiento opresivo occidental: nosotros y los otros, los propios y los ajenos, los indígenas y los blancos, lo andino y criollo, lo rural y urbano, lo tradicional frente a lo moderno; articulada también a la polaridad socialismo y capitalismo, explotado y explotador. Por ello se desarrolla una alta valoración de "todo" lo andino frente a "todo" lo occidental considerado como lo foráneo que debía ser extirpado. El discurso azorado y apasionado de la chakana ingresa con fuerza respaldando la revalorización de los elementos andinos perdidos durante la "evangelización" hispana en la Colonia y continuada por la aculturación del siglo XX. Entonces estas organizaciones culturales juveniles intelectuales asumen muchas ideas apasionadas que la corriente indigenista había construido sobre el mundo andino y que junto a la opción política de izquierda hace necesaria también la búsqueda del cambio social en pro de un utópico socialismo basado en lo andino. Sin embargo, toda esta posición racionalizada no ingresa a la esfera de lo privado y subjetivo de los integrantes, más aún en la década de los 2000 cuando, al contrario, se expresa públicamente el nuevo carácter del joven integrante de los sikuris.

12. La etapa prehispánica es considerada el momento histórico de donde se puede extraer los símbolos andinos en su "estado puro y pulcro", no contaminados por Occidente. La corriente indigenista del siglo XX en sus diferentes versiones, en su afán loable de investigación y recuperación de este pasado, exacerbó en muchos casos momentos del pasado andino reinventando por ejemplo fiestas como la "chakana raymi". Estos eventos son construidas desde estos ámbitos discursivos o de proyectos ideológicos en base a hipótesis y extrapolaciones, convirtiéndose por tanto en eventos a nivel de instituciones y no populares. Así aparece con fuerza el mismo símbolo de la chakana y los consiguientes eventos o fiestas. 


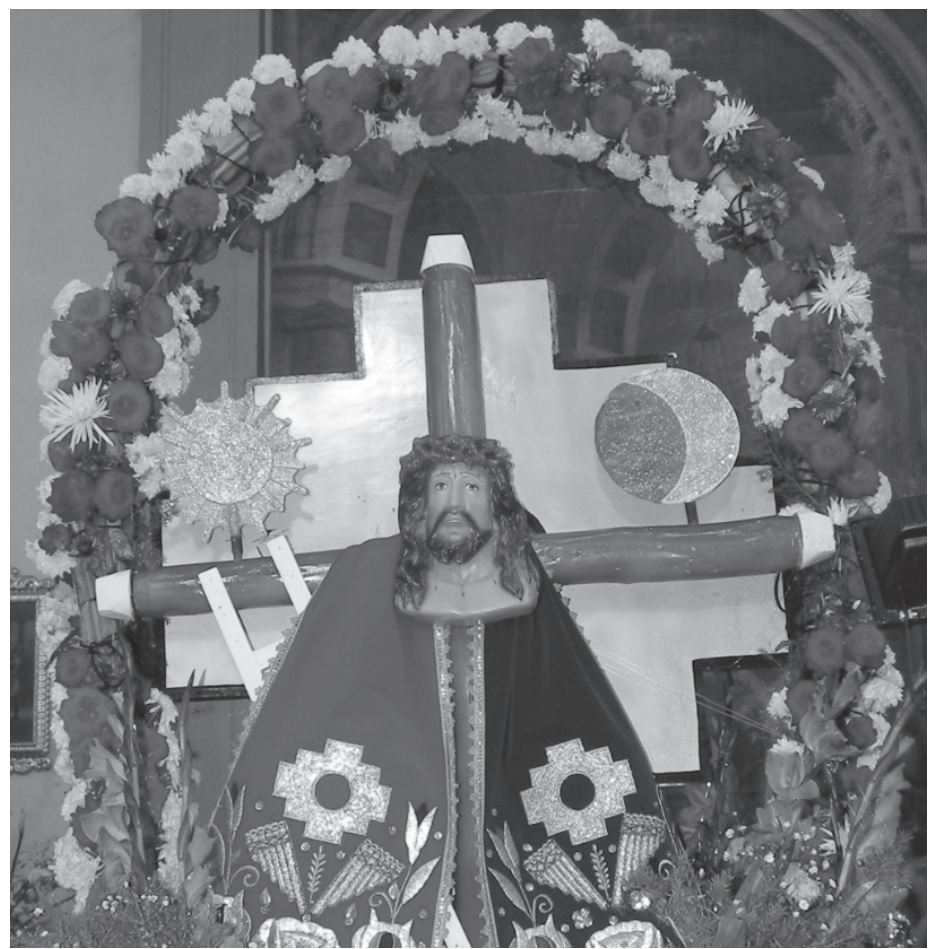

Fig. 5) En el Anda observamos la conjunción simbólica entre la imagen de la chakana o cruz andina y la cruz cristiana con la imagen de Jesucristo. A los lados, observamos a la luna y al sol, símbolos de la cosmovisión andina. ¿Conjunción de "lo occidental" con "lo andino"?

De esta manera esta nueva fiesta urbana se desarrolla como un proyecto andinista integrando confusamente e instrumentalizando elementos para la recuperación de la memoria histórica andina, el fortalecimiento de la costumbre, del folklore, de la tradición, del pueblo, de los Andes, etc. Apareciendo siempre la posibilidad de articularse a proyectos políticos e ideológicos ${ }^{13}$. Un claro ejemplo es la presión u obligación silenciosa que tienen los grupos de participar artísticamente en esta fiesta con la modalidad sikuri (varios bombos o sikuri mayor), no solo debido que en Huancané (Puno) los grupos que participan en esta fiesta son exclusivamente de esta modalidad, sino porque hay un trasfondo, el de considerar a esta modalidad como la expresión más tradicional, rural y auténtica del sikuri frente al sikumoreno (considerada como una construcción del "misti" y de la ciudad). De esta manera la fiesta de la chakana cruz ha sido convertida así en un símbolo ideológico / religioso que intenta representar el desencuentro entre Occidente (la cruz cristiana) y los Andes (la cruz chakana), representando la lucha entre el bien y el mal, entre lo rural y lo urbano, y el colectivismo y el individualismo. Es por ello tal vez que, como observamos en las figuras, el símbolo de la chakana es más grande y pesada que la cruz cristiana, y esta carga sobre sus espaldas a la chakana como queriendo revertir la situación de sometimiento, como castigándola y asemejándose al cóndor andino sobre el toro hispano en el Yawar Fiesta de José María Arguedas. Es decir, todo un lugar de significaciones juveniles urbanas donde alguna vez se intentó poner también la hoz y el martillo (símbolo comunista) de acuerdo a algunas versiones, no sabemos si antojadizas.

13. En algún momento, nos dicen, se intentó también colocar subliminalmente en el "anda" una hoz y un martillo (símbolos de la organización PCP-Sendero Luminoso). 
Esta intención de replicar una fiesta andina con el fin de difundir la cultura altiplánica, continuar con tradiciones andinas, agrupar a los conjuntos de sikuris bajo un argumento religioso o, más aún, recuperar rituales andinos pre cristianos, no termina construyendo una comunidad devota, más bien crea un novedoso espacio juvenil de distensión de los grupos de sikuris limeños, donde los pocos grupos de migrantes que participan son los que se encuentran más ligados a prácticas urbanas, y donde se conjugan elementos tan diversos y antagónicos, como la ideología y la religión, la identidad, la solidaridad y la competencia, los ritos paganos y la misa. Sin embargo, esta reinvención del símbolo de la chakana no crea una conciencia colectiva sobre lo andino en esta comunidad, pero crea un interesante espacio de participación y recreación de sus propias identidades.

Se trata de una fiesta nueva de los grupos de sikuris construida por y para ellos, por eso se inicia con la participación de conjuntos que no poseían cruces en Lima, que no pertenecían a una comunidad andina. En Lima, la colonia huancaneña ya había reimplantado la fiesta de las cruces en su formato de "continuidad cultural" que caracteriza a la mayoría de migrantes provincianos en Lima, sin embargo, había grupos (como los conjuntos de Conima) que no tenían fiesta de cruces, es decir había colonias puneñas que no tenían fiesta de cruces, por ello cuando la AJP hace el primer llamado para la realización de la fiesta de la cruz asisten prioritariamente estos grupos: "En Lima paralelo a las Cruz de Mayo (de Huancané) los grupos de Sikuris celebraban la fiesta de la Chakana Cruz iniciada por la Asociación Juvenil Puno como primer alferado con la participación de los grupos San Miguel de Tuito, los grupos de Conima (Progresista, Hilata, Centro Social, Qhantati)"14.

Esto hace que desde un primer momento esta "fiesta religiosa" reinventada tuviera una participación heterogénea: conjuntos regionales (migrantes), conjuntos metropolitanos (limeños) e híbridos (la AJP). El carácter contestatario ("progresista") de la AJP que lideraba entonces este proyecto, permitió el establecimiento de un gran sesgo "político cultural" a pesar de que formalmente se construye esta fiesta buscando fomentar una "conciencia religiosa" de tipo andino como el que le portarían las fiestas religiosas migrantes y los grupos regionales que participaban en ella. Su extensión a los nuevos miembros de la comunidad sikuri limeña (a los metropolitanos), le otorga nuevos elementos culturales construyendo una nueva expresión simbólica que se entremezcla entre un tipo de religiosidad racionalizada (pensada e imitada) y una participación artística altamente competitiva. No podía ser menos toda vez que los nuevos miembros de esta "comunidad chakana" eran principalmente jóvenes estudiantes universitarios en su mayoría de tendencia marxista, izquierdista o parte de proyectos socialistas que difícilmente se expresarían en términos de devoción o fe cristiana, tampoco andina. Finalmente, la AJP, fue un grupo que buscaba racionalizar e instrumentalizar las prácticas y acciones de los sikuris bajo sus objetivos políticos - culturalistas.

En este sentido, observamos además una aparente y grave incongruencia entre la práctica y el discurso de esta generación limeña (AJP y metropolitana) pues sus miembros individual y colectivamente apostaban por un proyecto político de izquierda que se caracteriza justamente por su desconexión con las prácticas o creencias religiosas cristianas o andinas. Aparente decimos, porque los conjuntos de sikuris metropolitanos que abiertamente esbozan (hasta la actualidad) su articulación a proyectos políticos de izquierda, no participan de esta fiesta ni en muchas otras actividades que involucran al movimiento metropolitano y regional (fiestas patronales, concursos, festivales, encuentros, etc.) ${ }^{15}$.

14. Constantino Vargas, integrante de la AJP en: http://www.sikurin-utapa

15. Al interior de la UNMSM encontramos actualmente a tres conjuntos de sikuris cuyo accionar al parecer responde a sus ideales o aspiraciones ideológicas y no se hacen presentes en esta fiesta: Sikuris César Vallejo, Sikuris José María Arguedas y Sikuris Taquimarca. 


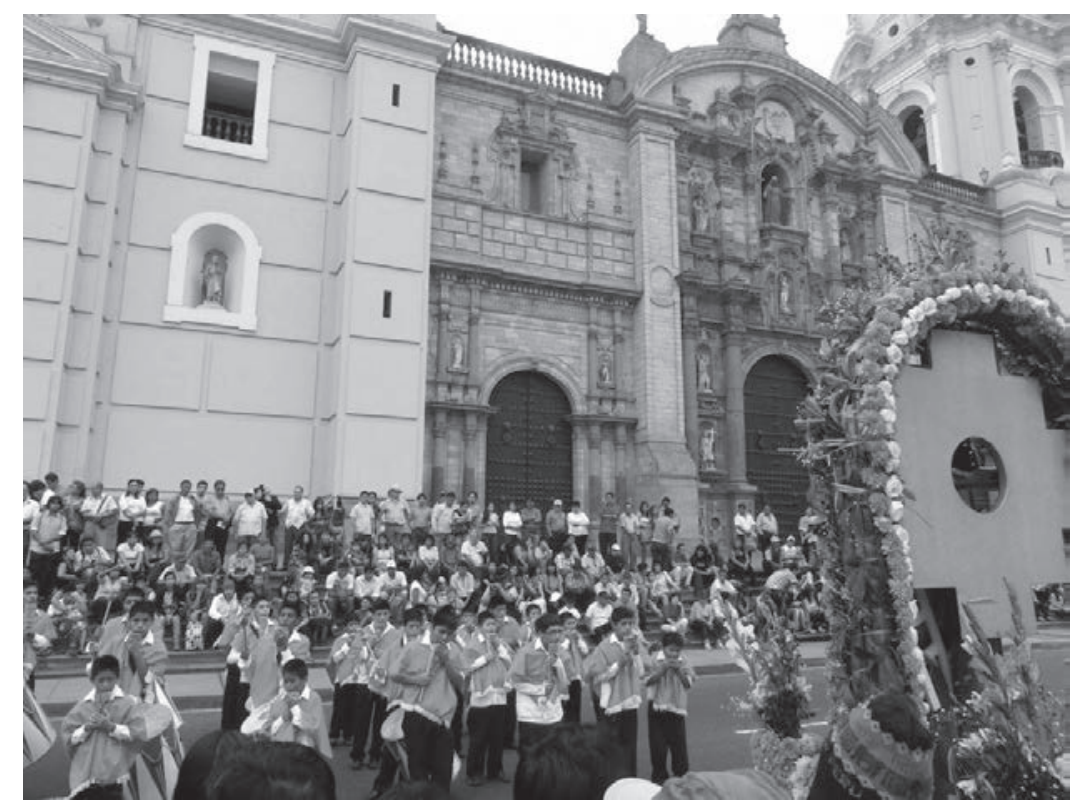

Fig. 7) La fiesta religiosa de la Chakana Cruz reinventada por los conjuntos limeños (regionales y metropolitanos), presenta moldes de las fiestas patronales y de la fiesta en honor a la Santísima Cruz de Mayo en Huancané (Puno), pero sin el ingrediente principal: fe y devoción.

La ausencia de un lenguaje religioso común y de elementos de culto religioso ( $\mathrm{fe}$, creencias, devoción, pasión, etc.) evidencia este evento más social y festivo que religioso, donde el gusto por la música sikuri, la competencia, la diferenciación (la identidad) se exhibe profusamente en un momento de negociación simbólica con elementos de tradición andina. Es posible que lo único que lo diferencie de un encuentro o concurso de sikuris, sea la misa, pues la gran procesión por las calles de Lima se asemeja mucho a los pasacalles previos a los encuentros de sikuris. De esta manera lo principal que podemos encontrar en esta festividad reinventada es su carácter híbrido: ya no se trata de acciones o eventos que reflejan la defensa de "lo andino" ni tienen que ver con la resistencia a los complejos procesos de imposición, interpenetración, extirpación y resistencia.

Todo esto, partiendo del hecho mismo que ni en las fiestas tradicionales altiplánicas de las cruces (en Huancané, por ejemplo) hay la posibilidad de la existencia de una religión andina no-cristiana (la antítesis de una religión cristiana), tampoco prácticas religiosas cristianas sin elementos andinos. Ocurre entonces un proceso de continua negociación simbólica donde lo cristiano ha penetrado los mismos ritos andinos, haciendo de la misma liturgia católica (y de la protestante) difícil de ubicarla como un fenómeno bien definido; una de estas expresiones es justamente la fiesta de cruces andinas. Estas expresiones son trasladadas a la ciudad de Lima por los migrantes andinos, quienes reconstituyen este tipo de eventos con cada vez más elementos cristianos y menos andinos. En esta dirección se ha querido posicionar el evento de la chakana cruz instaurada por la AJP, como también otras fiestas de cruces; por ejemplo las de Huancané y Moho en Lima, toda vez que viene incrementándose la participación protagónica de jóvenes urbanos provenientes de los conjuntos metropolitanos. Sin embargo, como hemos visto, la inclusión mayoritaria de los integrantes metropolitanos en desmedro de 
los grupos regionales ha cambiado el rostro de esta fiesta, siendo reconvertido por el nuevo carácter cultural de la población participante, en este caso juvenil y urbano. Fiestas que "integran" prácticas tradicionales andinas como modernas populares urbanas (como las músicas de reggaetón que suenan avanzada la fiesta), acciones que bien caen en lo que García Canclini denominó “prácticas híbridas” y más actualmente Jurgen Golte y Doris Leon "Jóvenes polifacéticos".

Por ello algunas fiestas de la chakana han terminado convertidas en fiestas populares marginales, muy cercanas a lo mundano, donde la irreverencia y los conflictos intergrupales afloran, donde la pugna por el prestigio, el individualismo, la competencia y la exhibición, motivan a sus participantes. Por ello algunas de las fiestas en los años 2000 han terminado con grandes grescas "matonescas", muy común en las fiestas de barrios marginales, o las conocidas fiestas "chichas" o a las "polladas".

Sin duda, se trata de un gran evento social alrededor del cual se motivan los grupos participantes, afloran sus intereses individuales y colectivos. Es un momento muy bien usado por los grupos para procurar fortalecerse internamente o para reencontrarse, e inter-grupalmente se constituye en un momento que desarrolla alta competencia, exaltándose la identidad grupal y las cotidianas diferencias $^{16}$. Es una fiesta donde los que pasan cargos de alferados también tejen sus propios intereses, evidenciándose una motivación mediática basada en, por ejemplo, la búsqueda de reconocimiento, protagonismo, legitimidad, etc. Lo importante para los alferados (cuando estos son metropolitanos) es el logro de su buena presencia, por ello no existe la búsqueda racional de la cohesión social -que toda fiesta de cruces busca- entre sus miembros. Sin embargo, un día de gran reunión festiva en la comunidad sikuri se halla garantizada. De esta manera podemos entender por qué para el año 2013 esta fiesta contaba con propuesta de alferados hasta por cinco años en adelante, la mayoría de estos, conjuntos metropolitanos. Por otro lado, estos últimos años se han ampliado a tres velaciones antes de la fiesta central; tales indicadores solo pueden expresar dos cosas: 1) La devoción por la fiesta estaría en pleno crecimiento y, 2) Se trata de un espacio de poder y prestigio muy apetecido por los conjuntos, en especial metropolitanos.

Esta cruz no es territorial, a diferencia de casi todas las cruces en Lima (popular y migrante); aunque sí ha logrado conformar una gran colectividad alrededor de ella (solo los días de fiesta), a ello se debe su consecuencia de carácter social. Los racionalizados e instrumentalizados intentos por recuperar y representar elementos autóctonos se desentienden con la mayor parte de los involucrados en este evento, toda vez que son en su mayoría jóvenes y los que a toda vista no participan en los pagos a la tierra, en los conversatorios o discusiones teóricas que se realizan los días previos a la fiesta.

\section{CONCLUSIONES}

Desde hace algunas décadas atrás las festividades religiosas altiplánicas en Lima se han convertido en un espacio que promueven formas de agrupamiento, prácticas, imaginarios e identidades. La estrecha relación sikuris - religión hace que sus escenarios de máxime desarrollo sean en estas ocasiones, trastocando inclusive su ciclo temporal tradicional. Las más grandes concentraciones de los sikuris en el Altiplano son por ejemplo: el 3 de febrero de honor a la Virgen de la Candelaria, el 29 de setiembre en honor al patrón San Miguel en Ilave como en Conima, el 10 de octubre en honor a San Francisco en Yunguyo, etc. Pero en el transcurso del siglo XX el sikuri realiza una nueva y gran

16. La máxima expresión de esto se dio el año 2007, cuando terminó en una batalla campal con heridos de gravedad y varias decenas de botellas de cervezas rotas producto de una gran gresca intergrupal (informes del CZSM). Otros informes también evidencian que el año 2013 en la misma fiesta, se desarrolló una "bronca" entre miembros del CZSM que llegó no solo a maltratos físicos, sino a la intervención de Serenazgo y denuncias policiales. 
migración a las ciudades y a nuevos espacios sociales dejando estos contextos básicamente rituales y empieza a formar parte de la vida social y cultural del nuevo poblador altiplánico en las mismas ciudades de Puno como en la capital peruana. En este tránsito, el sikuri también renueva muchos caracteres, acciones y perspectivas desvinculándose de lo ritual, de las actividades agrícolas, de su motivación religiosa, y convirtiéndose en una expresión cultural popular de consumo libre y masivo.

En estas circunstancias a inicios de los años 80 se reinventa la fiesta de la cruz impulsada por la AJP bajo el criterio indigenista o folklorista de la época de "recuperación y difusión". Por ello se trata de reconstituir esta fiesta en Lima y se convoca a los conjuntos regionales sin una clara intención de extender la invitación a los metropolitanos. El CZSM será el primero en ser aceptado cuando hacia finales de la década de los 80 se le confía la responsabilidad de ser el organizador (alferado), desde entonces y poco a poco los conjuntos metropolitanos se han incorporado a esta fiesta al punto que para la década de los 2000 encontramos una mayoritaria participación de estos, frente a la disminuida presencia de los conjuntos regionales: de acuerdo a los cuadros del presente título en los últimos doce años ha habido nueve alferados metropolitanos y tres regionales. Esta fiesta propia de los conjuntos de sikuris de Lima va a ser conocida como "La Chakana Cruz" y se ha constituido en uno de los acontecimientos más esperados por estos conjuntos, en especial por los metropolitanos, motivados por el carácter competitivo que tiene.

Sin embargo, por sus caracteres tengamos la presunción que esta fiesta tiene una falsa y enrevesada explicación teórica, puesto que en ella se confunden inconscientemente la cruz chakana, la cruz cristiana (Cristo) y la fiesta ritual en honor a la constelación de la Cruz del Sur que se encuentra íntimamente ligada al tiempo de cosechas. Esta confusión no ha sido aclarada, la devoción e importancia religiosa que posiblemente tuvo al inicio con la participación de los migrantes ha disminuido ostensiblemente con una evidente participación de "alferados sin devoción religiosa" y una juventud altamente desconectada de las prácticas religiosas tradicionales o populares. Esta fiesta ha crecido en número, en importancia para los conjuntos que pugnan por ser alferados, pero no en devoción religiosa. El deseo de "alferarse" la fiesta, no es sino una motivación de ser "organizador" de un evento que tiene seguidores y que posiciona al conjunto coyunturalmente, entonces variables como el poder y prestigio desconectadas del fervor religioso presentan una fiesta religiosa sin devotos, pero que pese a leerse contradictorio, existe y funciona, como funcionan muchas prácticas desconcertantes en este ámbito al que llamamos híbrido.

Por otro lado, el ritual de agradecimiento a la Pachamama por las cosechas en mayo (momento de la constelación de la Cruz del Sur), existe en los espacios rurales, campesinos, en un gran sincretismo con la devoción a la cruz cristiana; no existe sin embargo la devoción a la chakana propiamente dicha, esta ha quedado como un posible ritual ya fenecido y por tanto un término en desuso (más usado por los estudiosos que por la población); en la práctica misma no se encuentra la cruz cuadrada en ninguno de los rituales a lo largo del mundo andino, no la hemos visto tampoco en Huancané en época de la fiesta de las cruces y tampoco como término cotidiano. Sin embargo, en la fiesta de la que hablamos, el símbolo de la chakana tallada en un gran y pesado madero ha sido superpuesto a la cruz cristiana hacia finales de la década de los 90 en un afán de reivindicación de lo "más profundamente andino" y bajo un discurso un poco desordenado que combina cristianismo popular e indianismo puro con algo de marxismo. Por lo que en esta fiesta no encontramos continuidad o algún rasgo sobreviviente del culto a la constelación de la Cruz del Sur bajo el ropaje de la fiesta de las cruces de ninguna manera, en Lima no. Esta fiesta no representa un culto a la constelación del sur y ni por asomo a la chakana, la misma que muy por el contrario es considerada por Carlos Milla como un símbolo puramente matemático, de la ciencia andina que no tiene nada que ver con rituales religiosos andino-cristianos y tampoco festivos. 
Por lo tanto, creemos que estamos ante una fiesta social juvenil con huellas, elementos o rasgos andinos, urbanos y cristianos. Todos los ámbitos formales del ritual religioso son fielmente imitados con ciertas libertades de particularización: la misa, la procesión, los saludos o reverencias, etc. También se complementan con rasgos de "religiosidad andina": el pagapu o challa, el ayni, elecciones y cambio de alferados, etc. Decíamos además que el anda contiene una cruz latina o cristiana y sobre ella una cruz chakana construida en madero y que parecería que la primera carga a la segunda (Fig. 6). En el aspecto religioso, más allá del intento formal de cumplir con la misa y la procesión no existe mayor esfuerzo por ampliar o generar mayor fervor religioso. Por ejemplo, en las reuniones previas al evento a las que hemos asistido en varias oportunidades, los conjuntos participantes suelen discutir exclusivamente temas relacionados a "mejorar la fiesta" (por ello decimos que estas se asemejan más a reuniones previas a un concurso), pero nunca se ha discutido sobre "la falta de religiosidad en este evento", como "mejorar el fervor religioso" o "qué tipo de fervor religioso se debe practicar en la fiesta". Los acostumbrados "conversatorios" realizados con la intención de ahondar en el tema, siempre han estado dirigidos hacia una revisión del lado antropológico (cuando no ideológico) enfatizando más bien una perspectiva de confrontación dual entre "lo cristiano" y "lo indiano". Por otro lado, a lo largo de la fiesta en muchas ocasiones nos hemos detenido a observar las manifestaciones de devoción religiosa que los conjuntos y/o los participantes realizan frente a la imagen (que es lo común y acostumbrado en una fiesta religiosa de este tipo). Lamentamos decir que el anda (el mueble procesional) y la imagen permanecen prácticamente olvidados en una de las esquinas del local, aunque en algunas ocasiones hemos visto a ciertas personas mayores, visiblemente procedentes de los conjuntos migrantes, acercarse con gestos de devoción. Una de las principales razones subyacentes para este tipo de prácticas es que la mayoría de estos conjuntos metropolitanos devienen de compartir las visiones marxistas de la religión y los discursos indigenistas ${ }^{17}$. ¿Estamos entonces ante una fiesta religiosa donde el $99 \%$ de participantes no son devotos?

Tampoco se evidencia que haya efectivas acciones de "recuperación andina", de rituales o manifestaciones de lo que podemos llamar religión andina, salvo el pagapu o challa que se realiza en algunas ocasiones al inicio de la fiesta. Normalmente los conjuntos suelen decirse que actúan por "ayni", es decir ayuda y colaboración mutua entre ellos, sin embargo la mayoría de prácticas sociales de ayuda y solidaridad obedecen a situaciones solidarias comunes a todo grupo social. Por ejemplo, testimonialmente podemos dar fe de que es muy común que las apjatas (donaciones) inscritas con bastante compromiso en un cuaderno el día de fiesta, en gran medida son incumplidas al año siguiente. De esta manera creemos que esta fiesta se trata de un evento masivo, que representa o dibuja de cuerpo entero al movimiento, puesto que exhibe caracteres de una fiesta eminentemente juvenil, popular, urbana e inclusive marginal para la cultura urbana oficial. Sin embargo, tenemos la impresión de que lo que más bien subyace a esta fiesta aparentemente religiosa, es un nuevo tipo de agrupamiento juvenil, de expresión y competencia de las identidades grupales y el desarrollo de sus diferencias o conjunciones. Un evento altamente festivo juvenil donde el expendio del licor desarrolla los cánones de un "tono" (fiesta popular cotidiana) común de fin de semana. No existe por demás el esfuerzo y empeño en cumplir con las exigencias que una práctica o evento necesita para ser llamado un caso de "religiosidad popular", la que básicamente es entendida como un conjunto de "prácticas religiosas no institucionalizadas pero basadas en hondas creencias de fe y en Dios" (Puebla - III Conferencia del Episcopado Latinoamericano 1979).

17. El marxismo común consideraba a la religión "el opio del pueblo". Si bien esta es una concepción excesivamente simplista de la concepción marxista, era prácticamente el concepto que circulaba entre los ámbitos de los sikuris. 


\section{BiBLIOGRAFÍA}

ALTAMIRANO, Teófilo

1998 “Religión y religiosidad en el Perú”. Revista el Dorado Nº 11. Lima: PromPerú.

CALSIN A., René

2010 “Festividad Virgen de la Candelaria”. Revista Danzas Mestizas: Festividad Virgen de la Candelaria. Puno.

CAJAVILCA N., Luis

2007 "Metamorfosis de los dioses y las sacerdotisas andinos en Huamantanga (Canta), siglo XVII". Revista $N^{\circ} 18$ del Instituto de Investigaciones Histórico Sociales de la UNMSM. Lima.

CALLISAYA Carlos Cruz

2006 “La negociación simbólica: pureza doctrinal o sincretismo religioso?” Teología andina: el tejido diverso de la fe indígena. Instituto Superior Ecuménico Andino de Teología (ISEAT / editores). La Paz.

GARCÍA, Néstor

1999 Laglobalización imaginada. Buenos Aires: Editorial Paidós.

GARCÍA, Néstor

2001 Culturas híbridas, estrategias para entrar y salir de la modernidad. Buenos Aires: Editorial Paidós.

GEERTZ, Clifford

1993 [1973] La interpretación de las culturas. Barcelona: Gedisa.

GOLTE, Jürgen

1999 “Redes étnicas y globalización”. Revista de Sociología, vol. 11, N 12. Lima.

HANCCO R.

2012 “Rubén. La Asociación Juvenil Puno - AJP y la chakana en Lima”. Revista Siku. Centro Cultural Rimaq Wayra. Lima.

HOBSBAWM, Eric

2002 “Inventando tradiciones”. Historias № 19. Pp. 3-15. Introducción al libro The lnvention of Tradition, antología que Eric Hobsbawm preparó junto con Terence Ranger para Cambridge University Press. Traducción de Jorge Eduardo Aceves Lozano. México.

LAJO, Javier

2002 Qhapaq Kuna... más allá de la civilización. Cusco: Editorial Grano de Arena.

LANDIVAR, Manuel

1979 “Música folklórica y popular". Revista del Instituto Azuayo de Folklore. Nº 6, Cuenca: Instituto Azuayo de Folklore. 
MARZAL, Manuel

1988 "La fiesta patronal andina en la ciudad de Lima”. Revista Allpanchis N 31. Sicuani: Instituto de Pastoral Andina.

MARZAL, Manuel

1989 Los caminos religiosos de los inmigrantes en la Gran Lima. Lima: PUCP - CONCYTEC.

MILLA V., Carlos

1983 Génesis de la cultura andina. Fondo Editorial C.A.P. Colegio de Arquitectos del Perú.

ORTMANN, Dorothea

2002 Ciencias de la religión en el Perú. Lima: UNMSM Fondo editorial.

RAMIREZ B., Bernardino

2009 "La fiesta de las cruces, expresión del sincretismo cristiano-indígena". Investigaciones sociales Vol. 13, N²2, Lima: UNMSM/IIHS.

SÁNCHEZ H., Carlos

2000 b “Identidad y folklore: jóvenes migrantes en Lima”. URPICHA, Revista del Centro Universitario de Folklore de San Marcos. Lima.

SÁNCHEZ H., Carlos

2007 "Formación y desarrollo de los grupos de sikuris urbanos en lima: de la ideología y el esencialismo a la hibridación". Folklore: Arte, Cultura y Sociedad. Lima: UNMSM.

2008 “El estilo Ilave en los metropolitanos. Artículo en Chamanpi Sikuris". Boletín del Centro Universitario de Folklore. Lima: UNMSM.

2012 "El estilo en los conjuntos metropolitanos". Revista SIKU del Centro Cultural Rimaq Wayra. Lima.

2012 “Orígenes y evidencias de las primeras flautas de Pan en el Perú". Boletín Haylli № 19, Julio. Centro Universitario de Folklore. Lima: UNMSM.

2013 La flauta de pan andina: los grupos de sikuris metropolitanos. Lima: Fondo editorial UNMSM.

SCHAW, Federico

1996 Las fiestas de las cruces y la sobrevivencia de antiguos ritos pre-hispánicos. Lima: Fondo Editorial UNMSM.

VIDAL H., Carlos

2012 Presentación. Boletín Mundo Sikuri. Lima.

VILCAPOMA, José

2008 La danza a través del tiempo. Universidad Nacional Agraria La Molina. Lima. 